\title{
Infliximab for the treatment of plaque psoriasis
}

\author{
Jennifer S Gall \\ Robert E Kalb
}

State University of New York at Buffalo, School of Medicine and Biomedical Sciences, Department of Dermatology, NY, USA
Correspondence: Robert E Kalb

Buffalo Medical Group PC, 295 Essjay Rd, Buffalo, NY I422I.

$\mathrm{Tel}+\mathrm{I} 716630$ II02

Email kalb@buffalo.edu

\begin{abstract}
Infliximab is a monoclonal antibody that targets tumor necrosis factor- $\alpha$ (TNF $\alpha)$. It is used in the treatment of a number of inflammatory disorders including severe plaque psoriasis. TNF $\alpha$ is thought to have a major role in psoriasis by promoting an inflammatory infiltrate into the skin and inducing keratinocyte proliferation and preventing keratinocyte apoptosis, which directly contributes to the characteristic plaque skin lesions. Based on four randomized, placebo-controlled, double-blind clinical trials and nine open-label uncontrolled trials of the use of infliximab in plaque psoriasis, it was found that infliximab is a highly efficacious, rapid, sustainable, and relatively safe therapy. Yet as with any biologic, caution is recommended in its use as infusion reactions, lupus-like syndromes, infections, malignancies including lymphomas, as well as other rare events have been reported.
\end{abstract}

Keywords: infliximab, psoriasis, plaque

Psoriasis is a chronic inflammatory disease of the skin affecting at least 5.8 million people in the United States and 125 million people worldwide (National Psoriasis Foundation 2007; Gelfand et al 2005). The most common form of psoriasis, psoriasis vulgaris, occurs in more than $80 \%$ of cases. Less common forms include guttate psoriasis and erythrodermic and pustular psoriasis, which occur in approximately $10 \%$ and 3\% of patients, respectively (Lebwohl 2003). Psoriatic lesions may be pruritic and disfiguring, resulting in a significant negative physical and emotional impact in those affected. Feelings of depression, fear and embarrassment, as well as dissatisfaction with disease management, are widespread among persons suffering from psoriasis (Krueger et al 2001). In 10\%-30\% of psoriatic patients, nail dystrophy and psoriatic arthritis cause interference with many daily activities that require both fine and gross motor skills (Nickoloff and Nestle 2004). Psoriasis cannot be explained purely by genetics (Elder et al 2001) or environment; it has a complex immunopathology that is not fully understood.

\section{Immunopathology of psoriasis}

Psoriasis results from an abnormal activation of the immune system, with T cells in the epidermis and dermis playing a central role. The initial activation of $\mathrm{T}$ cells is unclear, but is thought to be due to a protuberance in epidermal keratinocytes from exogenous stimuli such as trauma and UV exposure, or endogenous stimuli such as infection and medications (eg, lithium and $\beta$-blockers) which through a "danger signal" leads to the activation of antigen presenting cells (APCs) such as Langerhans cells (Matzinger 2002; Nickoloff and Nestle 2004). Once activated, Langerhans cells migrate through the lymphatic system to surrounding lymph nodes where its MHCantigen complex is recognized by specific $\mathrm{T}$ cell receptors on naïve $\mathrm{T}$ cells. Full activation of $\mathrm{T}$ cells occurs with a costimulatory molecule on APCs combining with CD28 on $\mathrm{T}$ cells. The activated $\mathrm{T}$ cell expresses cutaneous lymphocyte-associated antigen (CLA) which allows access to the skin (Langley et al 2007). The abnormally activated 
T cells elaborate cytokines including tumor necrosis factor- $\alpha$ (TNF $\alpha$ ) and $\gamma$-interferon which contribute to a vicious cycle of inflammation and tissue damage, manifested clinically as plaque skin lesions (Nickoloff 1991).

\section{Role of TNF $\alpha$ in psoriasis}

TNF $\alpha$ is found in high concentrations in the skin lesions and plasma of patients with psoriasis and has a major role in the stimulation and propagation of immunological activity by targeting an inflammatory infiltrate into the skin (Turbitt et al 1990). TNF $\alpha$ upregulates the expression of vascular endothelial growth factor (VEGF) and intercellular adhesion molecule-1/vascular cell adhesion molecule-1 which promotes angiogenesis and microvascular permeability and targeting of lymphocytes to inflammatory lesions, respectively (Markham et al 2006). TNF $\alpha$ induces Langerhans cell maturation and migration to lymph nodes for further $\mathrm{T}$ cell activation and CLA expression. TNF $\alpha$ further stimulates lymphocyte migration, increasing the expression of many proinflammatory cytokines including CCL27 (a skin-specific memory T cell attractant) and NF-kB (a ubiquitous transcription factor) that leads to the expression of many gene products that mediate inflammatory responses (Banno et al 2004).

TNF $\alpha$ directly contributes to the characteristic plaque surmounted by silvery scales by inducing keratinocyte proliferation and preventing keratinocyte apoptosis via increasing vasoactive intestinal peptide (VIP) receptor and increasing plasminogen activator inhibitor type 2 , a serine protease inhibitor, respectively (Gottlieb 2003).

The advances in the understanding of $\mathrm{T}$ cells and specifically TNF $\alpha$ in psoriasis has led to the development of biologic agents that target them (Sauder and Mamelak 2004; Chong and Wong 2007; Langley et al 2007).

\section{Infliximab}

Infliximab is a chimeric monoclonal antibody comprised of human antibody constant regions and murine variable regions that was developed to specifically target TNF $\alpha$. Infliximab binds both soluble and membrane-bound TNF $\alpha$, preventing it from binding its receptor which results in a decrease in epidermal $\mathrm{T}$ cell infiltration. There is a significant reduction of T cells in the epidermis of psoriatic lesions after 48 hours of treatment with a single, low dose $(3 \mathrm{mg} / \mathrm{kg})$ infusion of infliximab (Goedkoop et al 2004).

Infliximab helps to control angiogenesis, a key factor in the proinflammatory state of psoriasis, by down-regulating angiopoietin, a growth factor critical for new blood vessel growth, and its receptor, Tie2 (Markham et al 2006).
Furthermore, anti-TNF $\alpha$ drugs like infliximab have been shown to restore neuroendocrine pathways (eg, hypothalamic - pituitary - adrenal axis) from the pro-inflammatory state that TNF $\alpha$ favors, and normalizes hormone levels (Straub et al 2006).

Complementary to its anti-inflammatory effect that is mediated through the neutralization of TNF $\alpha$, infliximab normalizes keratinocyte differentiation (Gottlieb et al 2003) and induces apoptosis of lesional keratinocytes through a caspase independent mechanism to further speed clinical improvement (ten Hove et al 2002; Kruger-Krasagakis et al 2006).

Infliximab is used to treat a number of inflammatory disorders including rheumatoid arthritis, Crohn's disease, and psoriatic arthritis (Markham and Lamb 2000; Woolacott et al 2006; Behm and Bickston 2007). In September 2006, the US FDA approved the use of infliximab in adults with chronic, severe plaque psoriasis (FDA 2006). This paper aims to review the efficacy and safety of infliximab in this setting based on a plethora of recently published research on the topic.

\section{Randomized, placebo-controlled, double-blind clinical trials}

Four randomized, controlled trials of infliximab in the treatment of plaque psoriasis have been reported in the literature (Table 1). Chaudhari and colleagues (Chaudhari et al 2001; Gottlieb et al 2003) conducted a small ( $n=33)$, phase II trial consisting of a patient population with moderate to severe plaque psoriasis involving a minimum of $5 \%$ body surface area (BSA) for at least 6 months. The patients were randomly assigned to one of three groups: $5 \mathrm{mg} / \mathrm{kg}$ infliximab $(\mathrm{n}=11), 10 \mathrm{mg} / \mathrm{kg}$ infliximab $(n=11)$, or placebo $(n=11)$. Infusions were given at 0,2 , and 6 weeks and followed by an open-label phase from weeks 10-26 in which relapsing patients were retreated as needed and placebo nonresponders were given an induction of infliximab. Beginning at week 2, the improvement in PASI (Psoriasis Area and Severity Index) scores were significantly $(\mathrm{p}<0.0003)$ higher in both infliximab treated groups. At week 10, the PASI 75 (at least 75\% improvement from baseline in PASI) was achieved in $82 \%$ and $73 \%$ of patients receiving 5 $\mathrm{mg} / \mathrm{kg}$ and $10 \mathrm{mg} / \mathrm{kg}$ infliximab, respectively, compared to only $18 \%$ of placebo patients ( $\mathrm{p}<0.05$ ). PASI 75 was maintained in $33 \%$ and $67 \%$ of the respective infliximab patients through week 26. Infusion reactions occurred in $9 \%$ of patients, but no other autoimmune events were reported. Reported adverse events (AE) were considered mild by the investigator and no serious adverse events (SAE) occurred. 


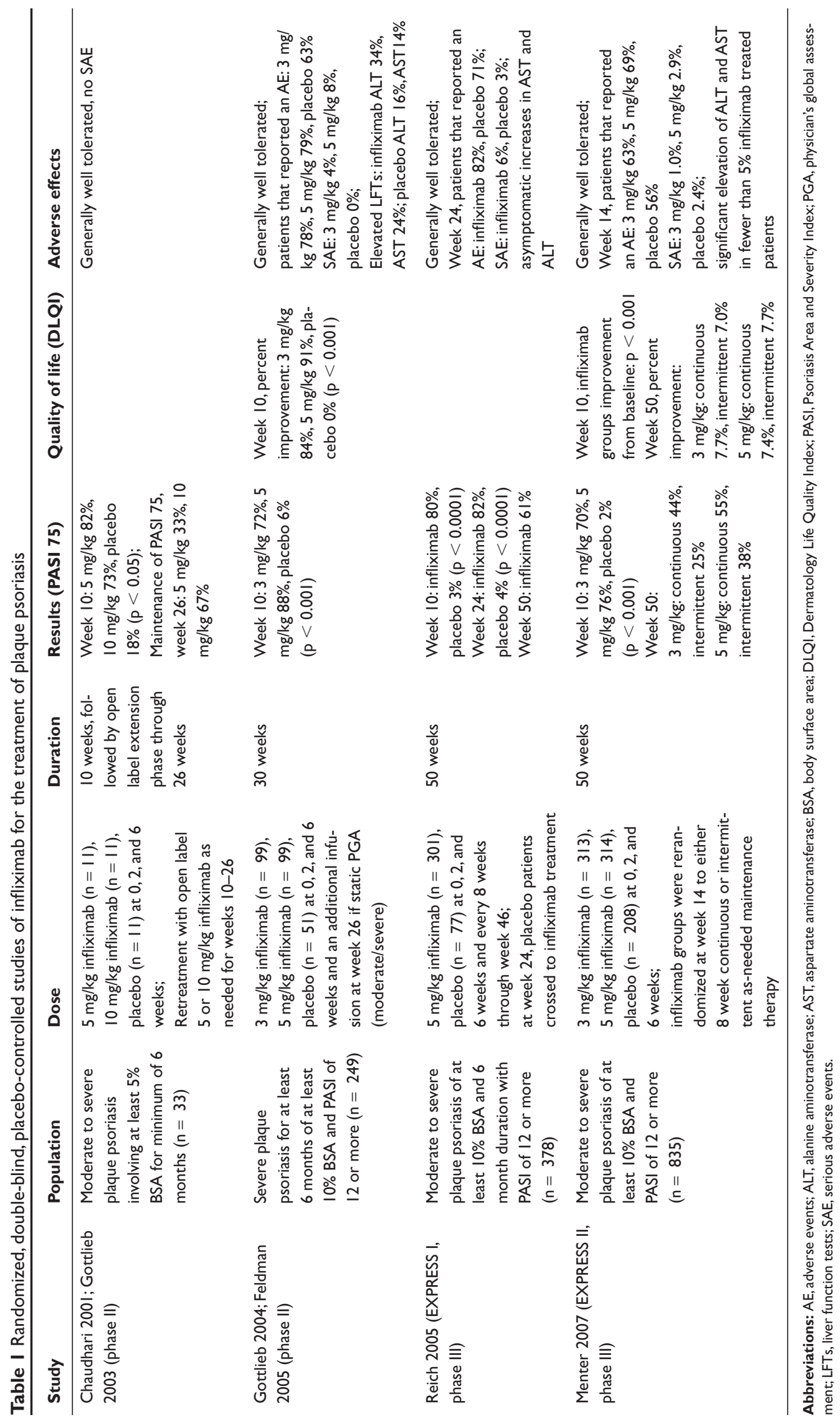


A larger $(n=249)$ phase II trial was conducted by Gottlieb and colleagues (Gottlieb et al 2004; Feldman et al 2005) that consisted of a study population with severe plaque psoriasis covering at least $10 \%$ BSA for 6 months or more and a PASI of at least 12. Patients were randomly assigned to either a $3 \mathrm{mg} / \mathrm{kg}$ infliximab ( $\mathrm{n}=99), 5 \mathrm{mg} / \mathrm{kg}$ infliximab ( $\mathrm{n}=99)$, or placebo $(\mathrm{n}=51)$ treatment group with infusions given at $0,2,6$ weeks, and an additional one at week 26 if a static Physician's Global Assessment (PGA) of moderate to severe psoriasis was made. At week 10, PASI 75 was achieved in $72 \%$ and $88 \%$ of $3 \mathrm{mg} / \mathrm{kg}$ and $5 \mathrm{mg} / \mathrm{kg}$ infliximab patients, respectively, compared to only $6 \%$ of placebo treated patients $(p<0.001)$. In two of the aforementioned studies (Chaudhari et al 2001; Gottlieb et al 2004), no significant differences were recorded between the two infliximab groups in inducing significant clearance, but larger dose infliximab groups, $10 \mathrm{mg} / \mathrm{kg}$ and $5 \mathrm{mg} / \mathrm{kg}$, respectively, maintained remission longer. The Dermatology Life Quality Index (DLQI) at week 10 was improved by $84 \%$ and $91 \%$, respectively, in infliximab treated patients compared to $0 \%$ in the placebo group $(\mathrm{p}<0.001)$. AE and SAE were reported in $78 \%$ and $4 \%$ of the $3 \mathrm{mg} / \mathrm{kg}$ patients, $79 \%$ and $8 \%$ of the $5 \mathrm{mg} / \mathrm{kg}$ patients, and $63 \%$ and $0 \%$ of the placebo patients, respectively. The lower percentage of $\mathrm{AE}$ in the placebo group could be partly a result of the high dropout rate in the placebo group and thus shorter follow-up. Yet four of the SAE in the infliximab groups - squamous cell carcinoma, cholecystitis and cholelithiasis, diverticulitis, and sepsis and pyelonephritis - were considered by the investigator to be reasonably related to infliximab therapy. Infusion reactions were reported in $18 \%$ and $22 \%$ of patients in the infliximab groups, respectively, compared to $2 \%$ of the placebo group. Through week 26 , $24 \%$ patients with antibodies to infliximab experienced infusion reactions compared to $22 \%$ antibody-negative patients The only noteworthy elevated lab values were the liver function tests (LFTs) aminotransferase (ALT) and aspartate aminotransferase (AST) in the infliximab groups (34\% and $24 \%$, respectively) compared to placebo (16\% and $14 \%$, respectively)

Reich et al (2005) reported the first multicenter phase III study of infliximab [European Infliximab for Psoriasis (Remicade) Efficacy and Safety Study/EXPRESS] in patients $(n=378)$ with moderate to severe plaque psoriasis of at least $10 \%$ BSA and 6 month duration with PASI of 12 or more. Patients were randomly placed into a $5 \mathrm{mg} / \mathrm{kg}$ infliximab or placebo group with infusions given at 0,2 , and 6 weeks and then every 8 weeks through week 46 . At week 24 , placebo patients were crossed to receive infliximab. At week 10 and
24 , PASI 75 was achieved in $80 \%$ and $82 \%$ of infliximab patients, but only $3 \%$ and $4 \%$ of placebo patients, respectively $(\mathrm{p}<0.0001)$. At week 50, PASI 75 was achieved in $61 \%$ of infliximab-treated patients. There was generally good tolerability to infliximab with AE and SAE at week 24 reported in $82 \%$ and $6 \%$ of infliximab-treated patients and $71 \%$ and $3 \%$ placebo-treated patients, respectively. With equal follow-up, similar proportions of patients in the infliximab and placebo groups were diagnosed with infections, but serious infections were more prevalent in the infliximab group. Malignancies, squamous and basal cell carcinomas, occurred in $1 \%$ of infliximab-treated patients but $0 \%$ in placebo-treated patients. In infliximab-treated patients, $3 \%$ had infusion reactions ( $2 \%$ in the placebo-treated patients) and two patients had a lupus-like syndrome. No clinically significant changes in hematological values were noted except for asymptomatic increases in AST and ALT.

Menter et al (2007) performed the largest phase III trial to date $(\mathrm{n}=835)$ with moderate to severe plaque psoriasis covering at least $10 \%$ BSA and PASI of 12 or more (Evaluation of Infliximab for Psoriasis in a Remicade Efficacy and Safety Study/EXPRESS II). Study participants were randomly assigned to a $3 \mathrm{mg} / \mathrm{kg}(\mathrm{n}=313), 5 \mathrm{mg} / \mathrm{kg}(\mathrm{n}=314)$, or placebo $(\mathrm{n}=208)$ group with infusions at 0,2 , and 6 weeks. At week 14 , the two infliximab groups were re-randomized to either 8 week continuous or intermittent as-needed therapy. At week 10 , PASI 75 was achieved in $70 \%$ and $76 \%$ of the $3 \mathrm{mg} / \mathrm{kg}$ and $5 \mathrm{mg} / \mathrm{kg}$ infliximab-treated patients, respectively, but only $2 \%$ of placebo-treated patients ( $\mathrm{p}<0.001)$. At week 50 , PASI 75 was achieved in $44 \%$ of the $3 \mathrm{mg} / \mathrm{kg}$ continuous group compared to $25 \%$ of the intermittent group, and $55 \%$ of the $5 \mathrm{mg} / \mathrm{kg}$ continuous group compared to $38 \%$ of the intermittent group. At week 10, both infliximab groups had a significant improvement in DLQI $(p<0.001)$. AE and SAE at week 14 occurred in $63 \%$ and $1.0 \%$ of the $3 \mathrm{mg} / \mathrm{kg}$ infliximab group and $69 \%$ and $2.9 \%$ of the $5 \mathrm{mg} / \mathrm{kg}$ infliximab group compared to $56 \%$ and $2.4 \%$ of the placebo group, respectively. Through week $14,12 \%$ and $10 \%$, in the infliximab groups, respectively, experienced an infusion reaction compared to $6 \%$ in the placebo group. While the majority of antibody-positive patients did not have an infusion reaction, an increased risk of a reaction was present in these patients compared to antibodynegative patients. Two cases of lupus-like syndrome occurred in the infliximab group compared to one in the placebo group (2:1 randomization of infliximab to placebo). Infection rates were similar in infliximab and placebo groups. Noteworthy adverse events in the infliximab group involved 2 cases of TB, 12 malignancies (1 breast carcinoma, 1 salpingeal 
adenocarcinoma, 1 squamous cell skin carcinoma, and 9 basal cell skin carcinomas) compared to 0 in the placebo group, and a significant elevation of ALT and AST in fewer than 5\% of infliximab-treated patients.

\section{Open-label, uncontrolled trials}

Nine open-label, uncontrolled trials of $5 \mathrm{mg} / \mathrm{kg}$ infliximab in the treatment of psoriasis have been reported (Table 2). In all trials, the majority of patients presented with plaque psoriasis but patients with erythrodermic and pustular psoriasis, acrodermatitis continua, and psoriatic arthritis are also included, and the patient population ranges from $n=7$ to $n=73$.

Chan and Gebauer (2003) demonstrated that a single $5 \mathrm{mg} / \mathrm{kg}$ infusion provided an average PASI and DLQI improvement at week 2 of $69 \%$ and $61 \%$, respectively, and at week $10(n=4)$ of $89 \%$ and $79 \%$, respectively, with no SAE reported.

In all the other open label studies $5 \mathrm{mg} / \mathrm{kg}$ infusions were given at a minimum of 0,2 , and 6 weeks. (Schopf et al 2002) demonstrated an average PASI improvement of $88 \%$ $(\mathrm{n}=8)$ at week 14. PASI 75 at week 10 was achieved in $79 \%$ (Cassano et al 2004) and 77\% of patients (Smith et al 2006) in trials consisting of 29 and 23 patients, respectively. At week 14, PASI 75 was achieved in $68 \%$ of patients in a trial of 28 patients (Poulalhon et al 2007). The magnitude of clinical improvement in the trials that reported PASI scores were similar to the randomized, controlled trials with PASI 75 at week 10 achieved in $76 \%$ to $88 \%$ of patients receiving $5 \mathrm{mg} / \mathrm{kg}$ infusions in these trials (Table 1).

Three trials measured improvement on the PGA scale: the first reported $88 \%$ of patients achieving almost clear improvement or better $(\mathrm{n}=52)$ (Kalb and Gurske 2005); a second reported $75 \%$ of patients achieving excellent improvement (n = 12) (Ahmad and Rogers 2006); and a third reported $89 \%$ of patients achieving significant improvement after 12-14 weeks of treatment (Haitz and Kalb 2007) .

Krathen et al (2006) reported that $51 \%$ of patients experienced no loss of efficacy, while $30 \%$ of patients experienced a loss of efficacy, and others discontinued their participation in the clinical trials due to adverse events or insurance difficulties.

AE were similar to those in the randomized, controlled trials with infusion reactions and infections being the most prevalent (Table 2). Serious infections included extrapulmonary tuberculosis, cellulitis (Smith et al 2006), sepsis, pneumonia, and chronic obstructive pulmonary disease (COPD) (Poulalhon et al 2007). Two studies reported elevated LFTs (Ahmad and Rogers 2006; Smith et al 2006), and one patient with a prior history of fatty liver secondary to methotrexate and alcohol was diagnosed with autoimmune hepatitis caused by infliximab (Smith et al 2006). Reported malignancies included single cases of breast cancer (Krathen et al 2006), skin cancer, metastatic renal cell carcinoma, and CD30+ cutaneous T cell lymphoma (Smith et al 2006). The latter occurred in a 56-yearold man with a 30-year history of immunosuppressive therapies including cyclosporine, methotrexate, alefacept, and fumaric acid esters after 3 infusions of infliximab.

\section{Efficacy}

The aforementioned clinical trials (Tables 1 and 2) demonstrate that infliximab provides a rapid (as early as 2 weeks) (Chaudhari et al 2001), highly efficacious, and sustainable (up to 50 weeks) therapy especially when given at continuous (8-week) maintenance intervals (Menter et al 2007) for the treatment of moderate to severe plaque psoriasis. Infliximab use leads to a significant improvement in the quality of life as assessed by DLQI in those affected by psoriasis (Gottlieb et al 2004; Menter et al 2007). This is a very important finding considering that psoriasis has an impact on an affected persons' physical and mental functioning comparable to that seen in cases of cancer, arthritis, hypertension, heart disease, diabetes, and depression (Rapp et al 1999).

\section{Safety}

Infliximab is generally well tolerated; infusion reactions are the most commonly reported adverse events, occurring in $16 \%$ infliximab-treated patients compared to $6 \%$ of placebotreated patients (Callen 2007). Infusion-related reactions can involve chills, fever, headache, flushing and urticaria, myalgia and arthralgia, nausea, dyspnea, and hypotension (Gottlieb et al 2004; Reich et al 2005; Menter et al 2007). Most infusion-related reactions are mild and usually can be ameliorated by reducing rate of infusion rather than discontinuing therapy. A delayed hypersensitivity reaction may also present 3-12 days after infusion and produce a serumsickness like reaction (Krishnan and Hsu 2004).

Acute and delayed hypersensitivity reactions are partly the result of autoantibody formation towards infliximab, a concern related to the infusion of any foreign protein (Schellekens 2002). Patients with infliximab antibodies have been shown to be more likely to have an infusion reaction when compared to those with no antibodies (Menter et al 2007). However the strength of this relationship is not definitive (Gottlieb et al 2004), and even the proportion of infusion reactions in infliximab and placebo groups have shown to be similar (Reich et al 2005). This issue requires further 
Table 2 Open-label, uncontrolled trials of infliximab for the treatment of plaque psoriasis

\begin{tabular}{|c|c|c|c|c|c|}
\hline Study & Population & Dose & Duration & Results & Adverse events \\
\hline Schopf 2002 & $\begin{array}{l}\text { Moderate to severe } \\
\text { psoriatic skin lesions } \\
(\mathrm{n}=8), 2 \text { also had } \\
\text { PsA }\end{array}$ & $\begin{array}{l}5 \mathrm{mg} / \mathrm{kg} \text { at } 0,2 \text {, and } \\
6 \text { weeks }\end{array}$ & 14 weeks & $\begin{array}{l}\text { PASI scores improved by } \\
88 \%\end{array}$ & No SAE \\
\hline Chan 2003 & $\begin{array}{l}\text { Plaque psoriasis } \\
(n=7)\end{array}$ & $\begin{array}{l}5 \mathrm{mg} / \mathrm{kg} \text { single dose } \\
\text { infusion }\end{array}$ & 10 weeks & $\begin{array}{l}\text { Week 2, average PASI } \\
\text { improvement: 69\%;Week } \\
10(n=4): 89 \% \text { Week 2, } \\
\text { DLQI improvement: 6I\%; } \\
\text { Week } 10(n=4): 79 \%\end{array}$ & No SAE \\
\hline $\begin{array}{l}\text { Cassano } \\
2004\end{array}$ & $\begin{array}{l}\text { I4 diffuse, I } 3 \text { plaque } \\
\text { with PsA, I eryth- } \\
\text { rodermic, I pustular } \\
(\mathrm{n}=29)\end{array}$ & $\begin{array}{l}5 \mathrm{mg} / \mathrm{kg} \text { at } 0,2, \\
6, \text { and as-needed } \\
\text { maintenance }\end{array}$ & 10 weeks & Week I0, PASI 75: 79\% & 2 infections \\
\hline Kalb 2005 & $\begin{array}{l}\text { Severe plaque } \\
\text { psoriasis }>33 \% \text { BSA } \\
(n=52)\end{array}$ & $\begin{array}{l}5 \mathrm{mg} / \mathrm{kg} \text { at } 0,2, \\
6,14 \text {, and main- } \\
\text { tenance every } \\
8 \text { weeks }\end{array}$ & $\begin{array}{l}4-33 \text { months, } \\
\text { median of } 22 \\
\text { months }\end{array}$ & $\begin{array}{l}88 \% \text { had at least almost } \\
\text { clear improvement on PGA } \\
\text { scale }\end{array}$ & $\begin{array}{l}9(17 \%) \text { infusion reactions, } 13 \\
\text { infections }\end{array}$ \\
\hline Smith 2006 & $\begin{array}{l}22 \text { chronic plaque } \\
\text { psoriasis, I pustular } \\
(n=23)\end{array}$ & $\begin{array}{l}5 \mathrm{mg} / \mathrm{kg} \text { at } 0,2 \text {, and } \\
6 \text { weeks; } 3 \text { or } 5 \\
\mathrm{mg} / \mathrm{kg} \text { maintenance } \\
\text { dose every } 8-10 \\
\text { weeks }\end{array}$ & $\begin{array}{l}\text { Up to } 21 \\
\text { months }\end{array}$ & Week I0, PASI 75: 77\% & $\begin{array}{l}4 \text { signficant elevations in LFTs; } \\
2 \text { severe systemic infections: } \\
\text { extrapulmonary tuberculosis } \\
\text { (splenic abscess) and cellulitis, } \\
25 \% \text { discontinued therapy due to } \\
\text { infusion reactions ( } 2 \text { ), thrombo- } \\
\text { cytopenia (I), hepatitis (I), renal } \\
\text { cell carcinoma (I), and CD30+ } \\
\text { cutaneous T cell lymphoma (I) }\end{array}$ \\
\hline $\begin{array}{l}\text { Krathen } \\
2006\end{array}$ & $\begin{array}{l}\text { Moderate to severe } \\
\text { plaque psoriasis } \\
(n=73)\end{array}$ & $\begin{array}{l}5 \mathrm{mg} / \mathrm{kg} \text { at } 0,2 \text {, and } \\
6 \text { weeks; mainte- } \\
\text { nance dose every } \\
5 \text { to } 8 \text { weeks }\end{array}$ & $\begin{array}{l}\text { At least } 12 \\
\text { months }\end{array}$ & $\begin{array}{l}30 \% \text { discontinued treat- } \\
\text { ment secondary to loss } \\
\text { of efficacy as determined } \\
\text { by PGA; } 51 \% \text { no loss of } \\
\text { efficacy }\end{array}$ & $\begin{array}{l}7 \% \text { experienced minor } A E \\
\text { leading to discontinuation; } 4 \% \\
\text { SAE leading to discontinuation: } \\
\text { reactivation of TB, breast cancer, } \\
\text { Gl bleeding }\end{array}$ \\
\hline $\begin{array}{l}\text { Ahmad } \\
2006\end{array}$ & $\begin{array}{l}\text { I0 chronic plaque } \\
\text { psoriasis, I pustular, } \\
\text { I acrodermatitis } \\
\text { continua }(n=\mid 2)\end{array}$ & $\begin{array}{l}5 \mathrm{mg} / \mathrm{kg} \text { at } 0,2,6 \text {, } \\
\text { and maintenance } \\
\text { every } 8 \text { weeks }\end{array}$ & & $\begin{array}{l}9 \text { had PGA of excellent } \\
\text { improvement, } 2 \text { good PGA } \\
\text { but became resistant, I } \\
\text { failed to respond }\end{array}$ & $\begin{array}{l}\text { I infusion reaction, I neutrope- } \\
\text { nia, } 3 \text { elevated LFT's }\end{array}$ \\
\hline $\begin{array}{l}\text { Poulalhon } \\
2007\end{array}$ & $\begin{array}{l}20 \text { plaque psoriasis, } \\
5 \text { psoriatic eryth- } \\
\text { roderma, } 3 \text { pustular } \\
\text { psoriasis }(n=28)\end{array}$ & $\begin{array}{l}5 \mathrm{mg} / \mathrm{kg} \text { at } 0,2 \text {, and } \\
6 \text { weeks; mainte- } \\
\text { nance dose every } \\
8 \text { weeks }\end{array}$ & $\begin{array}{l}22-185 \text { weeks, } \\
\text { median of } 78 \\
\text { weeks }\end{array}$ & Week I4, PASI 75: 68\% & $\begin{array}{l}\text { I8\% SAE: delayed infusion } \\
\text { reaction (I), polyarthralgias (2), } \\
\text { infectious complications (2) I4\% } \\
\text { severe bacterial infections: com- } \\
\text { munity-acquired pneumonia (2), } \\
\text { COPD (I), sepsis (I) }\end{array}$ \\
\hline Haitz 2007 & $\begin{array}{l}\text { Chronic plaque } \\
\text { psoriasis previously } \\
\text { treated with etaner- } \\
\text { cept }(n=19)\end{array}$ & $\begin{array}{l}5 \mathrm{mg} / \mathrm{kg} \text { at } 0,2, \\
6 \text {, and } 14 \text { weeks; } \\
\text { maintenance dose } \\
\text { every } 14 \text { weeks }\end{array}$ & $\begin{array}{l}4-25 \text { months, } \\
\text { median of } 8 \\
\text { months }\end{array}$ & $\begin{array}{l}\text { After } 12 \text { to } 14 \text { weeks of } \\
\text { treatment, } 89 \% \text { showed a } \\
\text { significant improvement in } \\
\text { PGA and BSA }\end{array}$ & $\begin{array}{l}47 \% \text { experienced minor infec- } \\
\text { tions }\end{array}$ \\
\hline
\end{tabular}

Abbreviations: AE, adverse events; BSA, body surface area; DLQI, Dermatology Life Quality Index; COPD, chronic obstructive pulmonary disease; GI, gastrointestinal; PASI, Psoriasis Area and Severity Index; PGA, physician's global assessment; PsA, psoriatic arthritis; LFTs, liver function tests; SAE, serious adverse events; TB, tuberculosis.

investigation but the potential for subsequent reactions during infusion demands close monitoring.

Another concern related to formation of antibodies to infliximab is the decreased efficacy of infliximab over time which may require increased infusion frequencies or higher doses to maintain a clinical response and disease control (Haitz and Kalb 2007; Shear 2006). Patients with neutralizing antibodies are less likely to maintain a response to infliximab 
than those negative for antibodies, but this does not determine clinical responsiveness (Reich et al 2005; Menter et al 2007). When infliximab is used in the treatment of Crohn's disease, there is a significant correlation between the development of antibodies against infliximab and increased risk of infusion reactions and shorter duration of response (Schellekens 2002). This relationship is much less clear in the treatment of plaque psoriasis as no randomized, placebo-controlled trials have been performed to date. From our experience, the frequency of infliximab administration for the treatment of plaque psoriasis should be based on clinical response rather than antibody status. We have found that when the clinical response to infliximab is waning, increasing the frequency of infliximab infusions is more effective than the addition of low dose methotrexate.

TNF $\alpha$ inhibition is associated with a lupus-like syndrome, which is also thought to be partly the result of an antibody response following infliximab infusion (Costa et al 2007; Ramos-Casals et al 2007). In the aforementioned randomized, controlled trials of 378 (Reich et al 2005) and 835 (Menter et al 2007) patients with psoriasis, two patients in each study had a lupus-like syndrome. It should be noted that in the latter case, one patient in the placebo group was diagnosed with the syndrome with a 2:1 randomization of infliximab to placebo (Menter et al 2007).

Infliximab's anti-TNF $\alpha$ effects hamper the immune system's role in defense against infections and malignancies. In the clinical use of infliximab, infection is the chief concern with upper respiratory infections being the most common (Gottlieb et al 2003; Reich et al 2005; Menter et al 2007). In the randomized, controlled clinical studies, there is no clinically significant increase in infection risk with infliximab compared to placebo (Reich et al 2005; Menter et al 2007). Yet, serious infections (Reich et al 2005) and malignancies (Gottlieb et al 2004; Reich et al 2005; Menter et al 2007) are more prevalent in the infliximab groups, demonstrating the importance of monitoring for malignancy and infection. No additional safety concerns are found for the $5 \mathrm{mg} / \mathrm{kg}$ dose compared to the $3 \mathrm{mg} / \mathrm{kg}$ dose (Menter et al 2007).

In individuals undergoing infliximab therapy for a variety of autoimmune disorders, serious infections have been seen with the following agents: Pneumocystis jiroveci, Mycobacterium tuberculosis, Listeria monocytogenes, Candida albicans, Aspergillus fumigatus, Histoplasma capsulatum, Cryptococcus neoformans, and Coccidioides immitis - infections typical of the immunocompromised (Ellerin et al 2003; Kaur and Mahl 2007). A case of osteomyelitis in a patient without a history of trauma who received infliximab therapy for severe psoriasis and psoriasis arthritis has recently been reported (Sri et al 2007).

Specifically, tuberculosis is a concern as TNF $\alpha$ plays a central role in defense against mycobacterial infections and containment of existing infections (Gardam et al 2003). The reactivation of latent tuberculosis is a well-known complication of infliximab therapy. A review of 70 cases of tuberculosis that developed after the initiation of treatment with infliximab found that the majority (56\%) of patients present with extrapulmonary tuberculosis while $24 \%$ had disseminated disease, forms of tuberculosis associated with immunosuppression (Keane et al 2001). These results have been reaffirmed in subsequent clinical trials (Krathen et al 2006; Smith et al 2006). This atypical presentation as well as higher incidence of extensive infection underlines the importance of screening for tuberculosis prior to therapy by patient history, a tuberculin skin test, a chest radiograph, and maintaining a high degree of clinical suspicion throughout treatment.

MedWatch received 8 reports of lymphoma in approximately 121,000 patients $(6.6 / 100,000)$ that used infliximab between May 1999 and December 2000 for rheumatoid arthritis (RA) and Crohn's disease (CD), with the lymphomas occurring within a median of 6 weeks after initiation of therapy (Brown et al 2002). It is unclear whether the lymphomas developed directly from the use of infliximab, pre-existing medical conditions, or other immunosuppressive agents that the patients were receiving. The aforementioned clinical trials of infliximab in the treatment of psoriasis documented a single case of CD30+ cutaneous T cell lymphoma in a patient previously treated with multiple immunosuppressive therapies (Smith et al 2006). Thus, the majority of data supporting a relationship between infliximab therapy and lymphoma risk comes from RA and CD patients. The risk of lymphoma in psoriasis patients treated with infliximab has not clearly been established.

Clinical trials have demonstrated a slight increase in malignancy in patients treated with infliximab. The two largest randomized, controlled clinical trials of infliximab in the treatment of psoriasis found 2\% (Menter et al 2007) and 1\% (Reich et al 2005) of 627 and 298 infliximab-treated patients experiencing a malignancy, respectively, compared to 0 in placebo-treated patients, the majority being skin cancers. However, long-term registry data with larger numbers of patients have not shown an association between biologic therapy and the development of solid tumors or lymphoma. There is an association with skin cancers in this registry group (Wolfe and Michaud 2007). 
Much of the evidence supporting a relationship between malignancy and TNF $\alpha$ antagonist therapy is derived from the treatment of rheumatoid arthritis patients. A cohort study of patients treated with biologic disease-modifying antirheumatic drugs (DMARDs) including etanercept, infliximab, adalimumab, and anakinra for rheumatoid arthritis found 11 hematologic malignancies and 46 solid tumors during 2940 person-years of DMARD use, and a pooled hazard ratio of 1.37 (95\% confidence interval, $0.71-2.65)$ and 0.91 (95\% confidence interval, $0.65-1.26)$ for the respective malignancies when compared to methotrexate-treated patients (Setoguchi et al 2006). A review of nine randomized, placebocontrolled trials of the use of infliximab or adalimumab in the treatment of rheumatoid arthritis found a dose-dependent increased risk of malignancy in patients treated with anti-TNF antibody therapy compared to placebo with a pooled odds ratio for malignancy of 3.3 (95\% confidence interval, 1.2-9.1) (Bongartz et al 2006).

Preliminary experimental evidence suggested a link between elevated TNF $\alpha$ and congestive heart failure (CHF) and that inhibition of TNF $\alpha$ could favorably modify the course of the disease (Torre-Amione et al 1996; Feldman et al 2000). This theory was discounted when three largescale clinical trials of the TNF $\alpha$ inhibitors, infliximab (Chung et al 2003a) and etanercept (Anker and Coats 2002), used in the treatment of CHF were halted for lack of benefit or adverse outcomes. The infliximab trial revealed that shortterm infliximab therapy did not improve patients with CHF, and high doses $(10 \mathrm{mg} / \mathrm{kg})$ adversely affected patients with CHF ( $p=0.043$ ) (Chung et al 2003b). MedWatch data also suggest that TNF $\alpha$ antagonists may induce heart failure in certain patients (Kwon et al 2003). No adverse cardiac events were reported in the trials of patients receiving infliximab therapy for psoriasis (Tables 1 and 2).

Infliximab is associated with cases of central nervous system involvement including rare demyelinating disorders (Mohan et al 2001; Robinson et al 2001). The clinical trials of infliximab in the treatment of psoriasis found that no cases of CNS disease resulted from this therapy (Tables 1 and 2). The causal relationship is weak if it exists at all, but it is recommended that the use of infliximab and other $\mathrm{TNF} \alpha$ antagonists be avoided in patients with a history of demyelinating disease, and that therapy be discontinued when neurologic symptoms occur.

Elevations in serum ALT and AST are fairly commonly reported (Tables 1 and 2), but associated hepatobiliary problems are much less frequent. In a letter to healthcare professionals regarding the potential of hepatotoxicity due to infliximab therapy, the US FDA reported 35 post-marketing and 3 clinical trial events of severe hepatitic reactions including acute liver failure, jaundice, autoimmune hepatitis, and cholestasis (Important drug warning 2004). In clinical trials of the use of infliximab in plaque psoriasis reviewed here (Tables 1 and 2), a single case of autoimmune hepatitis due to infliximab was reported in a patient previously diagnosed with fatty liver (Smith et al 2006). Hepatitis has also been reported in a patient undergoing infliximab therapy for psoriasis in the absence of autoimmune disease and previous liver damage (Wahie et al 2006). In both patients, previous methotrexate use and alcohol consumption are contributing factors. It is thought that concurrent methotrexate and infliximab therapy may exert synergistic effects on liver function, underlying the importance of close monitoring of liver function tests, especially in patients with a history of methotrexate use and alcohol consumption.

The extensive clinical trials and cases referenced above as well as physician experience has allowed the detection of the aforementioned rare adverse events. More long-term safety data has to be collected to establish a definitive relationship between these adverse events and infliximab in the treatment of psoriasis. Infliximab has generally been well tolerated in the more than 924,000 patients that have received infusions (Remicade 2007).

\section{References}

Ahmad K, Rogers S. 2006. Three years' experience with infliximab in recalcitrant psoriasis. Clin Exp Dermatol, 31:630-3.

Anker SD, Coats AJS. 2002. How to RECOVER from RENAISSANCE? The significance of the results of RECOVER, RENAISSANCE, RENEWAL and ATTACH. Int $J$ Cardiol, 86:123-30.

Banno T, Gazel A, Blumenberg M. 2004. Effects of tumor necrosis factoralpha in epidermal keratinocytes revealed using global transcriptional profiling. J Biol Chem, 279:32633-42.

Behm BW, Bickston SJ. 2007. Efficacy of infliximab for luminal and fistulizing Crohn's disease and in ulcerative colitis. Curr Treat Options Gastroenterol, 10:171-7.

Centocor. 2007. Remicade [online]. Accessed 26 Nov 2007. www.remicade.com.

FDA. 2006. Biologic license application efficacy supplements approved [online]. Accessed 15 June 2007. http://www.fda.gov.

Bongartz T, Sutton AJ, Sweeting MJ, et al. 2006. Anti-TNF antibody therapy in rheumatoid arthritis and the risk of serious infections and malignancies: systematic review and meta-analysis of rare harmful effects in randomized controlled trials. JAMA, 295:2275-85.

Brown SL, Greene MH, Gershon SK, et al. 2002. Tumor necrosis factor antagonist therapy and lymphoma development: twenty-six cases reported to the Food and Drug Administration. Arthritis Rheum, 46:3151-8.

Callen JP. 2007. Complications and adverse reactions in the use of newer biologic agents. Semin Cutan Med Surg, 26:6-14.

Cassano N, Loconsole F, Amoruso A, et al. 2004. Infliximab monotherapy for refractory psoriasis: preliminary results. Int J Immunopathol Pharmacol, 17:373-80. 
Chan JJ, Gebauer K. 2003. Treatment of severe recalcitrant plaque psoriasis with single-dose intravenous tumour necrosis factor-alpha antibody (infliximab). Australas J Dermatol, 44:116-20.

Chaudhari U, Romano P, Mulcahy LD, et al. 2001. Efficacy and safety of infliximab monotherapy for plaque-type psoriasis: a randomised trial The Lancet, 357:1842-7.

Chong BF, Wong HK. 2007. Immunobiologics in the treatment of psoriasis. Clin Immunol, 123:129-38.

Chung ES, Packer M, Lo KH, et al. 2003a. Randomized, double-blind, placebo-controlled, pilot trial of infliximab, a chimeric monoclonal antibody to tumor necrosis factor- $\{$ alpha $\}$, in patients with moderate-tosevere heart failure: Results of the Anti-TNF Therapy Against Congestive Heart failure (ATTACH) Trial. Circulation, 107:3133-40.

Chung ES, Packer M, Lo KH, et al. 2003b. Randomized, double-blind, placebo-controlled, pilot trial of infliximab, a chimeric monoclonal antibody to tumor necrosis factor-alpha, in patients with moderate-tosevere heart failure: results of the anti-TNF therapy against congestive heart failure (ATTACH) trial. Circulation, 107:3133-40.

Costa MF, Said NR, Zimmermann B. 2007. Drug-induced lupus due to anti-tumor necrosis factor agents. Semin Arthritis Rheum. Oct 29 [Epub ahead of print]

Elder JT, Nair RP, Henseler T, et al. 2001. The genetics of psoriasis 2001: the odyssey continues. Arch Dermatol, 137:1447-54.

Ellerin T, Rubin RH, Weinblatt ME. 2003. Infections and anti-tumor necrosis factor therapy. Arthritis Rheum, 48:3013-22.

Feldman AM, Combes A, Wagner D, et al. 2000. The role of tumor necrosis factor in the pathophysiology of heart failure. $\mathrm{J} \mathrm{Am} \mathrm{Coll} \mathrm{Cardiol,}$ 35:537-44.

Feldman SR, Gordon KB, Bala M, et al. 2005. Infliximab treatment results in significant improvement in the quality of life of patients with severe psoriasis: a double-blind placebo-controlled trial. $\mathrm{Br} J$ Dermatol, 152:954-60.

Gardam MA, Keystone EC, Menzies R, et al. 2003. Anti-tumour necrosis factor agents and tuberculosis risk: mechanisms of action and clinical management. Lancet Infect Dis, 3:148-55.

Gelfand JM, Stern RS, Nijsten T, et al. 2005. The prevalence of psoriasis in African Americans: results from a population-based study. $J \mathrm{Am}$ Acad Dermatol, 52:23-6.

Goedkoop AY, Kraan MC, Teunissen MBM, et al. 2004. Early effects of tumour necrosis factor alpha blockade on skin and synovial tissue in patients with active psoriasis and psoriatic arthritis. Ann Rheum Dis, 63:769-73.

Gottlieb AB. 2003. Infliximab for psoriasis. J Am Acad Dermatol, 49:112-7.

Gottlieb AB, Chaudhari U, Mulcahy LD, et al. 2003. Infliximab monotherapy provides rapid and sustained benefit for plaque-type psoriasis. $J \mathrm{Am}$ Acad Dermatol, 48:829-35.

Gottlieb AB, Evans R, Li S, et al. 2004. Infliximab induction therapy for patients with severe plaque-type psoriasis: a randomized, double-blind, placebo-controlled trial. J Am Acad Dermatol, 51:534-42.

Gottlieb AB, Masud S, Ramamurthi R, et al. 2003. Pharmacodynamic and pharmacokinetic response to anti-tumor necrosis factor-alpha monoclonal antibody (infliximab) treatment of moderate to severe psoriasis vulgaris. J Am Acad Dermatol, 48:68-75.

Haitz KA, Kalb RE. 2007. Infliximab in the treatment of psoriasis in patients previously treated with etanercept. $J$ Am Acad Dermatol, 57:120-5.

MedWatch. 2004. Important drug warning [online]. Accessed 8 July 2007. URL: http://www.fda.gov.

Kalb RE, Gurske J. 2005. Infliximab for the treatment of psoriasis: clinical experience at the State University of New York at Buffalo. J Am Acad Dermatol, 53:616-22.

Kaur N, Mahl T. 2007. Pneumocystis jiroveci (carinii) pneumonia after infliximab therapy: a review of 84 cases. Dig Dis and Sci, 52:1481-4.

Keane J, Gershon S, Wise RP, et al. 2001. Tuberculosis associated with infliximab, a tumor necrosis factor alpha-neutralizing agent. $N$ Engl $J$ Med, 345:1098-104.
Krathen RA, Berthelot CN, Hsu S. 2006. Sustained efficacy and safety of infliximab in psoriasis: a retrospective study of 73 patients. J Drugs Dermatol, 5:251-4.

Krishnan RS, Hsu S. 2004. Serum sickness due to infliximab in a patient with psoriasis. J Drugs Dermatol, 3:305-8.

Krueger G, Koo J, Lebwohl M, et al. 2001. The impact of psoriasis on quality of life: results of a 1998 national psoriasis foundation patientmembership survey. Arch Dermatol, 137:280-4.

Kruger-Krasagakis S, Galanopoulos VK, Giannikaki L, et al. 2006. Programmed cell death of keratinocytes in infliximab-treated plaque-type psoriasis. Br J Dermatol, 154:460-6.

Kwon HJ, Cote TR, Cuffe MS, et al. 2003. Case Reports of Heart Failure after Therapy with a Tumor Necrosis Factor Antagonist. Ann Intern Med, 138:807-11.

Langley RG, Gupta AK, Cherman AM, et al. 2007. Biologic therapeutics in the treatment of psoriasis. Part 1: review. J Cutan Med Surg, 11:99-122.

Lebwohl M. 2003. Psoriasis. The Lancet, 361:1197-204.

Markham, Mullan, Golden M, et al. 2006. Resolution of endothelial activation and down-regulation of Tie 2 receptor in psoriatic skin after infliximab therapy. Journal of the American Academy of Dermatology, 54:1003-12.

Markham A, Lamb HM. 2000. Infliximab: A review of its use in the management of rheumatoid arthritis. Drugs, 59:1341-59.

Matzinger P. 2002. The danger model: a renewed sense of self. Science, 296:301-5.

Menter A, Feldman SR, Weinstein GD, et al. 2007. A randomized comparison of continuous vs. intermittent infliximab maintenance regimens over 1 year in the treatment of moderate-to-severe plaque psoriasis. $J$ Am Acad Dermatol, 56:31.e1-.e15.

Mohan N, Edwards ET, Cupps TR, et al. 2001. Demyelination occurring during anti-tumor necrosis factor therapy for inflammatory arthritides. Arthritis Rheum, 44:2862-9.

National Psoriasis Foundation. 2007. About psoriasis: statistics [online]. Accessed 14 June 2007. www.psoriasis.org.

Nickoloff BJ. 1991. The cytokine network in psoriasis. Arch Dermatol, 127:871-84.

Nickoloff BJ, Nestle FO. 2004. Recent insights into the immunopathogenesis of psoriasis provide new therapeutic opportunities. J Clin Invest, 113:1664-75.

Poulalhon N, Begon E, Lebbe C, et al. 2007. A follow-up study in 28 patients treated with infliximab for severe recalcitrant psoriasis: evidence for efficacy and high incidence of biological autoimmunity. Br J Dermatol, 156:329-36.

Ramos-Casals M, Brito-Zerón P, Muñoz S, et al. 2007. Autoimmune diseases induced by TNF-targeted therapies: analysis of 233 cases. Medicine, 86:242-51.

Rapp SR, Feldman SR, Exum ML, et al. 1999. Psoriasis causes as much disability as other major medical diseases. $J$ Am Acad Dermatol, 41:401-7.

Reich K, Nestle FO, Papp K, et al. 2005. Infliximab induction and maintenance therapy for moderate-to-severe psoriasis: a phase III, multicentre, double-blind trial. The Lancet, 366:1367-74.

Robinson WH, Genovese MC, Moreland LW. 2001. Demyelinating and neurologic events reported in association with tumor necrosis factor alpha antagonism: by what mechanisms could tumor necrosis factor alpha antagonists improve rheumatoid arthritis but exacerbate multiple sclerosis? Arthritis Rheum, 44:1977-83.

Sauder DN, Mamelak AJ. 2004. Understanding the new clinical landscape for psoriasis: a comparative review of biologics. J Cutan Med Surg, $8: 205-12$.

Schellekens H. 2002. Immunogenicity of therapeutic proteins: clinical implications and future prospects. Clin Ther, 24:1720-40.

Schopf RE, Aust H, Knop J. 2002. Treatment of psoriasis with the chimeric monoclonal antibody against tumor necrosis factor alpha, infliximab. $J$ Am Acad Dermatol, 46:886-91.

Setoguchi S, Solomon DH, Weinblatt ME, et al. 2006. Tumor necrosis factor alpha antagonist use and cancer in patients with rheumatoid arthritis. Arthritis Rheum, 54:2757-64. 
Shear NH. 2006. Fulfilling an unmet need in psoriasis: do biologicals hold the key to improved tolerability? Drug Saf, 29:49-66.

Smith CH, Jackson K, Bashir SJ, et al. 2006. Infliximab for severe, treatment-resistant psoriasis: a prospective, open-label study. Br J Dermatol, $155: 160-9$.

Sri JC, Tsai CL, Deng A, et al. 2007. Osteomyelitis occurring during infliximab treatment of severe psoriasis. J Drugs Dermatol, 6:207-10.

Straub RH, Härle P, Sarzi-Puttini P, et al. 2006. Tumor necrosis factor-neutralizing therapies improve altered hormone axes: an alternative mode of antiinflammatory action. Arthritis Rheum, 54:2039-46.

ten Hove T, van Montfrans C, Peppelenbosch MP, et al. 2002. Infliximab treatment induces apoptosis of lamina propria Tlymphocytes in Crohn's disease. Gut, 50:206-11.

Torre-Amione G, Kapadia S, Lee J, et al. 1996. Tumor necrosis factoralpha and tumor necrosis factor receptors in the failing human heart. Circulation, 93:704-11.
Turbitt ML, Akhurst RJ, White SI, et al. 1990. Localization of elevated transforming growth factor-alpha in psoriatic epidermis. J Investig Dermatol, 95:229-32.

Wahie S, Alexandroff A, Reynolds NJ. 2006. Hepatitis: a rare, but important, complication of infliximab therapy for psoriasis. Clin Exp Dermatol, 31:460-1.

Wolfe F, Michaud K. 2007. Biologic treatment of rheumatoid arthritis and the risk of malignancy: analyses from a large US observational study. Arthritis Rheum, 56:2886-95.

Woolacott NF, Khadjesari ZC, Bruce IN, et al. 2006. Etanercept and infliximab for the treatment of psoriatic arthritis: a systematic review. Clin Exp Rheumatol, 24:587-93. 